\title{
Seed Transmission of the High Plains virus in Sweet Corn
}

\author{
R. L. Forster, University of Idaho Research \& Extension Center, Kimberly 83341; D. L. Seifers, Kansas State \\ University Agricultural Research Center - Hays, Hays 67601; C. A. Strausbaugh, University of Idaho, Research \& \\ Extension Center, Kimberly; S. G. Jensen and E. M. Ball, USDA/ARS, University of Nebraska, Lincoln 68583- \\ 0722; and T. L. Harvey, Kansas State University Agricultural Research Center - Hays, Hays
}

\begin{abstract}
Forster, R. L., Seifers, D. L., Strausbaugh, C. A., Jensen, S. G., Ball, E. M., and Harvey, T. L. 2001. Seed transmission of the High Plains virus in sweet corn. Plant Dis. 85:696-699.

The High Plains virus (HPV), which infects corn and other cereals, was first found in 1993 in the United States. Research was initiated in 1995 to investigate the potential for seed transmission of HPV. Sweet corn seeds of various cultivars harvested in 1994 to 1996 from 13 fields and research plots in southwestern Idaho, Colorado, and Nebraska were seeded in potting mix in the greenhouse. Leaf samples collected at the three- to six-leaf stage from both symptomatic and asymptomatic plants were tested by enzyme-linked immunosorbent assay (ELISA). Of the 46,600 seeds planted, 38,473 seedlings emerged, and three tested positive by ELISA, exhibited mosaic symptoms, and had the presence of HPV confirmed by an additional test. One of the positive plants was used for successful acquisition and transmission of HPV by the wheat curl mite to Westford barley. The other two plants were used to successfully transfer HPV to other corn plants by vascular puncture inoculation of seed. These results indicate that HPV can be seed transmitted at a very low frequency in sweet corn.
\end{abstract}

In 1993, a previously unknown pathogen was found in corn (Zea mays) in Colorado, Idaho, Kansas, and Texas (6). The pathogen had associated with it a $32-\mathrm{kDa}$ protein, and antiserum prepared against this protein preferentially reacted to it in enzyme-linked immunosorbent assay (ELISA) and Western blotting experiments $(6,13)$. Thread-like virus particles from symptomatic corn leaves infected by this pathogen have been observed in electron microscope studies (1). These particles were preferentially labeled when probed in immunogoldlabeling experiments using antiserum to the 32-kDa protein. In this same study, thin-sections made from infected cells were probed with the same antiserum, and the lumen, but not the membranes of the

\section{Corresponding author: Robert L. Forster \\ E-mail: forster@kimberly.uidaho.edu}

Published as Idaho Agricultural Experiment Station Journal Series Article 99718.

This work was supported in part by a grant from the American Seed Research Foundation. Appreciation is extended to personnel of the following seed companies for assistance in the disease surveys and harvesting: Charter Seed Co., Crookham Co., Harris Moran Seed Co., Novartis Seeds, Inc., and Seminis Vegetable Seeds.

Accepted for publication 5 March 2001.

Publication no. D-2001-0427-01R

(C) 2001 The American Phytopathological Society double-membrane bodies found in diseased tissue (6), were decorated with the goldlabeled antibodies. In other studies, dsRNA has been identified in infected tissue $(5,12)$. The sequence of one of the dsRNA segments was determined and deposited as U60141 in the GenBank (J. S. Hall et al., 1996). It was stated in this deposition that a tryptic peptide sequence from the $32-\mathrm{kDa}$ protein matched a portion of the dsRNA sequence, indicating that the dsRNA coded for the $32-\mathrm{kDa}$ protein. Thus, these data support the viral etiology of the pathogen since named the High Plains virus (HPV) (6).

During 1993, eight fields of sweet corn in Gooding and Jerome counties in south central Idaho, totaling about 304 ha, had symptomatic plants with disease incidences ranging from 30 to $85 \%$, and 154 of those hectares were abandoned due to the disease. In 1994 to 1996, the disease also developed in several sweet corn seed fields in southwestern Idaho (R. L. Forster, unpublished). Establishment of HPV in that area is consistent with the knowledge that it is transmitted only by the wheat curl mite (Aceria tosichella Keifer 1969 (Amrine and Stasny 1994), syn. A. tulipae) (13), which is present in Idaho. Several grain crops, including wheat, barley, oats, rye, and corn, and weeds including yellow foxtail (Setaria glauca (L.) Beauv.), green foxtail (S. viridis (L.) Beauv.), and downy brome (Bromus tectorum L.) are hosts of this virus (14). In several instances, high disease incidences were noted in sweet corn fields adjacent to wheat fields. Disease incidence declined as distance from the wheat increased, which is consistent with observations concerning spread of HPV by A. tosichella from volunteer wheat (13). Long distance movement of HPV, however, is not likely to be accomplished by mite dispersal, and seed transmission of HPV has not been investigated.

Seed transmission can be a serious problem with some plant viruses. In the case of Barley stripe mosaic virus, seed transmission is the major mechanism of spread of the virus (18). With other viruses, seed transmission may be rare and significant in the epidemiology only as a means for the introduction of viruses into new areas where they may further spread and become established if suitable vectors and hosts are available. This mode of virus spread is of great concern in modern agriculture, where it is common for large amounts of seed stock to be moved between regions or continents to take advantage of different growing seasons.

Very low levels of seed transmission of viruses in corn have been documented in several reports. Maize dwarf mosaic virus (MDMV) was transmitted at a low level, with only one seed transmission in 22,189 seedlings in one study (10), one seed transmission in 11,448 seedlings in another study (4), and two transmissions in 29,735 seedlings in a third study (19). Similarly, Zhu et al. (20) reported 14 seed transmissions of MDMV-B, now known as Sugar cane mosaic virus-MDB, in 22,925 seedlings. Shepard and Holdeman (16) found somewhat higher transmission of MDMV, with 17 transmissions from 9,485 seeds, but 14 of these came from one lot of 3,163 seeds. Jensen et al. (7) found 21 seed transmissions of Maize chlorotic mottle virus in over 42,000 seeds tested. Again, there was one source of seed that had most of the seed transmissions, so there may be a genotype or a point of origin influence on seed transmission.

Idaho produces about $90 \%$ of the United States domestic supply of sweet corn seed and exports about 4.5 million pounds annually. Since HPV is a newly identified virus, the objective of this research was to determine whether HPV is transmitted 
through sweet corn seed. An abstract of this work has been published previously (3).

\section{MATERIALS AND METHODS}

Sources of antiserum. Antiserum against HPV was prepared and used as previously described (13). Antiserum to Wheat streak mosaic virus (WSMV) was prepared using previously described procedures (15).

Indirect ELISA. The procedure used was as previously described (13). Leaf tissue in all studies was ground at 1:30 (wt/vol) in coating buffer $(0.05 \mathrm{M}$ carbonate buffer, $\mathrm{pH}$ 9.6) (2). Antiserum to HPV was used at a 1:50,000 ( $\mathrm{vol} / \mathrm{vol})$ dilution $(1.0 \mu \mathrm{g} / \mathrm{ml})$ made from a $1: 100$ crossabsorbed stock in ELISA blocking buffer

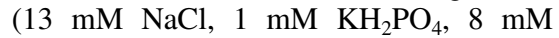
$\mathrm{Na}_{2} \mathrm{HPO}_{4}, 2.6 \mathrm{mM} \mathrm{KCl}, 0.5 \mathrm{ml}$ of Tween $20,20.0 \mathrm{~g}$ of polyvinylpyrrolidone [molecular weight 40,000 ], $2.0 \mathrm{~g}$ of ovalbumin,

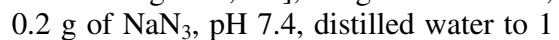
liter) as previously described (13). The goat antirabbit antibody:alkaline phosphatase conjugate $(1: 3,000)$ (Sigma Chemical Co., St. Louis, MO) and WSMV antibodies $(1 \mu \mathrm{g} / \mathrm{ml})$ were diluted using ELISA blocking buffer (2). All samples, antibody solutions, and substrate solutions were used in 200- $\mu$ l volumes. Substrate ( $p$ nitrophenyl phosphate, $0.714 \mathrm{mg} / \mathrm{ml}$ ) in substrate buffer (2) was added, and the plates were incubated at room temperature. The absorbance $(405 \mathrm{~nm})$ was measured after 30 min (Titertek Multiskan microelisa plate reader, Flow Laboratories, Inc., Huntsville, AL). The positive threshold for HPV detection by ELISA was considered 0.100 for the A. tosichella acquisition of HPV from corn and vascular puncture inoculations from corn to corn done at the Hays, KS, location. This value was based on previously determined Western blot confirmations $(13,14)$. Positive thresholds for detection of HPV in corn at the Nebraska location were considered twice that of the healthy control.

Seed sources. Surveys of sweet corn seed fields were conducted in late July and August in 1995 and 1996 in the Canyon County vicinity in southwestern Idaho to identify potential sources of HPV-infected seed. Symptomatic plants exhibiting wide chlorotic, mosaic leaf streaks and occasionally stunting and/or general chlorosis were marked with orange paint on the stalk for subsequent ear harvest, and leaf samples from a representative subset of these marked plants were collected for laboratory verification of HPV by ELISA. At harvest, ears from the marked plants were collected in burlap sacks, dried, and threshed by hand. In addition, sweet corn seeds from several miscellaneous sources, including commercial seedlots, and from known or suspected HPV-infected plants in plots or fields were received from cooperators in Nebraska, Colorado, and Idaho for verification of HPV by ELISA. Thirteen seedlots were evaluated in total.

Greenhouse grow-out tests. The timing and location of these grow-out tests and assays were aimed to minimize the possibility of contamination by airborne $A$. tosichella. Grow-out tests were conducted in the greenhouse at Kimberly, ID, during the winter and spring of 1995-96 and 1996-97. During this time, there were no cultures of A. tosichella or virus being maintained at the Idaho facility. In the area surrounding the facility, winter wheat was dormant and mites were not active. In Kansas and Nebraska, where assays for the virus were done, there were cultures of A. tosichella and the virus, but samples from Idaho were never exposed to them.

Seeds were planted in plastic trays $(27 \times$ $53 \mathrm{~cm})$ in a greenhouse potting mix $(80 \%$ compost $+20 \%$ vermiculite by volume), which was pasteurized in the composting process prior to our purchase from Organix Supply, Inc., Missoula, MT. Seed trays had five rows with 10 seeds per row and were placed on greenhouse benches with no supplemental lighting. Mean germination of all seedlots was $83 \%$ with a range of 28 to $98 \%$. Most of the tests were conducted at $34^{\circ} \mathrm{C}$ day and $21^{\circ} \mathrm{C}$ night temperatures; however, conditions for the first six replications of one seedlot comprising 8,855 seedlings were maintained at $29^{\circ} \mathrm{C}$ day and $12^{\circ} \mathrm{C}$ night temperatures. Temperatures were raised for the remainder of the study when other data (D. L. Seifers, unpublished) indicated that better symptom expression was achieved at the higher temperatures. Potted wheat (Triticum aestivum L.) seedlings were interspersed among the flats of corn as indicators to detect contamination by airborne mites.

Corn seedlings were observed at least once a week from the one-leaf stage until the five- to six-leaf stage for symptoms of disease or other unusual characteristics, and any such seedlings were labeled for subsequent testing. Either one leaf or the whole seedling (in cases when the seedling was stunted) was removed and sent by overnight mail to Lincoln, NE, or Hays, $\mathrm{KS}$, for ELISA to confirm the presence of HPV. In addition, leaves from 10 symptomless seedlings per flat were similarly removed and submitted for simultaneous testing to check for latent infections.

Maintenance of, and infestation of plants by, wheat curl mites. A. tosichella (Kansas culture) were of the same source and maintained on wheat cv. Tomahawk as previously described (13). Leaf samples of plants used as a source for A. tosichella for HPV acquisition were assayed by ELISA for HPV and WSMV prior to use. Identity of A. tosichella was confirmed by J. W. Amrine (West Virginia University).

To acquire the HPV, leaf pieces from wheat infested with adult or second instar mites (positive or negative in ELISA for WSMV only) were clipped to HPV source plants (corn), and the mites were allowed a 24-h acquisition period. The mites were then manually transferred (using a hair glued to a wooden dowel) to barley $\mathrm{cv}$. Westford from the suspected HPV-infected corn. The source plants and test plants were covered with plastic cages both before and after infestation as previously described (13).

Inoculum preparation for vascular puncture inoculations. Fresh inoculum was prepared by grinding (1:5 wt/vol) corn leaves with a wooden applicator stick (Fisher 01-340) in a 1.5-ml microfuge tube containing MBS-EDTA buffer $(0.2 \mathrm{M}$ mannitol, $0.07 \mathrm{M}$ sucrose, $0.5 \mathrm{M}$ tris- $\mathrm{HCl}$, 0.01 M EDTA, 0.022 M NaDIECA, 0.022 $\mathrm{M}$ sodium sulfite, $0.005 \mathrm{M}$ dithiothreitiol).

The vascular puncture inoculation was similar to that described by Louie (8) and Louie and Seifers (9). Corn seed (Country Gentleman and/or Spirit) were given a preinoculation soak (100 seeds in $50 \mathrm{ml}$ of distilled water) for $4 \mathrm{~h}$ at $4^{\circ} \mathrm{C}$ or $2 \mathrm{~h}$ at $30^{\circ} \mathrm{C}$. Seeds $(100)$ were placed in a $21 \times 21$ $\times 5 \mathrm{~cm}$ glass dish lined with eight sheets of paper towels moistened with $50 \mathrm{ml}$ of water. Five microliters of inoculum was placed on the embryo side of each kernel. Each seed was then inoculated using a single minutien pin mounted in an inoculating loop holder (Thomas Scientific, 7011-D70), with the loop holder mounted on an electric engraver (Burgess Model 74, New York Mills, NY - Fisher 13-389-10). The stroke of the engraver was adjusted to approximately the midpoint. The minutien pin was held at an angle of approximately 45 degrees from the kernel adjacent to the embryo and pushed through the inoculum and the pericarp covering the scutellum at five different locations along one side of the embryo to a depth of approximately 1 $\mathrm{mm}$. Following inoculation, the glass dish containing the seeds and the wetted paper towels was covered with clear plastic wrap and incubated at $30^{\circ} \mathrm{C}$ for $48 \mathrm{~h}$. The seeds were then planted into $30 \times 50 \mathrm{~cm}$ soilfilled metal flats with 10 seeds per row. Each flat was lightly watered and held in a greenhouse under natural lighting with a temperature range of 17 to $27^{\circ} \mathrm{C}$.

\section{RESULTS}

Grow-out tests. A total of 38,452 seedlings (from 46,600 seeds from 13 seed lots) were evaluated. Three of the seedlings (each from a different lot) developed mosaic symptoms within the first 3 to 4 weeks of growth (i.e., prior to the fifth-leaf stage of development), were positive by ELISA for only HPV in tests conducted at the Hays location, and were confirmed by an additional test, as described below. Two leaves from these plants are illustrated in Figure 1. Three additional symptomatic, HPV-infected seedlings were identified by ELISA but were not confirmed by an additional test due to the tedious, timeconsuming nature of the assays. 
Acquisition of HPV from corn by $A$. tosichella. The presence of HPV in the first symptomatic corn seedling (35A-1) was indicated by ELISA $\left(A_{405 \mathrm{~nm}}\right.$ was 0.277 and 0.016, respectively, against HPV and WSMV antisera). Because A. tosichella was demonstrated to be the vector of HPV (13), we further verified the presence of HPV by infesting the symptomatic corn seedling with nonviruliferous mites (wheat from which mites were obtained tested negative by ELISA for HPV). In the controls, no transmission of HPV or WSMV to barley occurred using nonviruliferous mites obtained from healthy corn. However, when mites were fed on HPV-positive corn (35A-1) and then transferred to barley, six barley plants developed symptoms and tested positive for HPV only (range of ELISA values was 0.102 to 0.169 ), two barley plants tested positive for HPV and

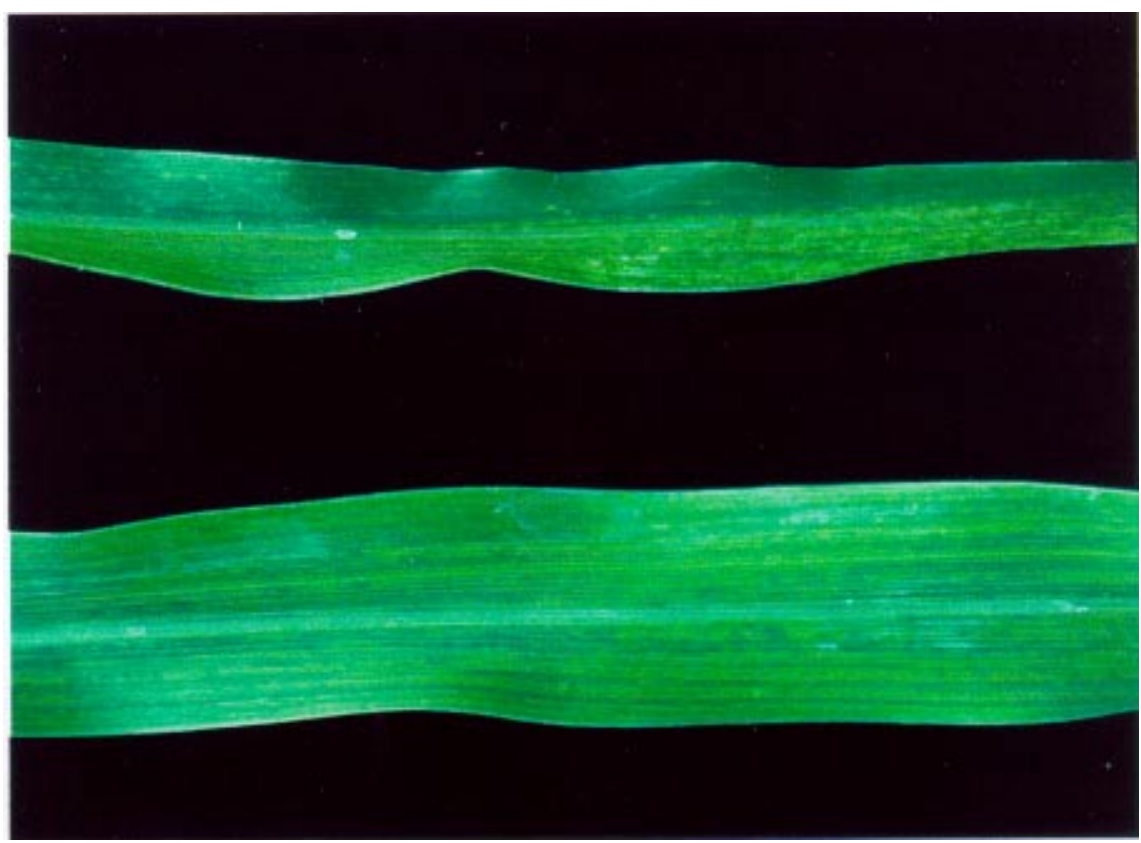

Fig. 1. Symptoms of natural seed transmission of High Plains virus (HPV) in seedling sweet corn leaves from plant 9706-6-1 (above) and plant 9712-2-1 (below) exhibiting mosaic and broad chlorotic leaf streaks very similar to symptoms in HPV-infected mature plants in the field.

Table 1. Confirmation of enzyme-linked immunosorbent assay (ELISA) results by vascular puncture inoculation (VPI)

\begin{tabular}{|c|c|c|c|c|c|}
\hline \multirow[b]{2}{*}{ Source plant ${ }^{a}$} & \multicolumn{2}{|c|}{ ELISA OD $^{b}$} & \multirow{2}{*}{$\begin{array}{c}\text { Seed soak } \\
\text { temperature }\end{array}$} & \multirow[b]{2}{*}{ Cultivar $^{\mathrm{c}}$} & \multirow{2}{*}{$\begin{array}{l}\text { Number of HPV } \\
\text { positive plants }\end{array}$} \\
\hline & HPV & WSMV & & & \\
\hline \multirow[t]{4}{*}{$9706-6-1$} & 0.969 & 0.142 & $4^{\circ} \mathrm{C}$ & $\mathrm{CG}$ & $5 / 33$ \\
\hline & & & $4^{\circ} \mathrm{C}$ & $\mathrm{S}$ & $4 / 40$ \\
\hline & & & $30^{\circ} \mathrm{C}$ & $\mathrm{CG}$ & $1 / 41$ \\
\hline & & & $30^{\circ} \mathrm{C}$ & $\mathrm{S}$ & $11 / 53$ \\
\hline B19 & 0.264 & 0.081 & \multicolumn{2}{|c|}{ Not used for VPI } & \\
\hline Y19 & 0.197 & 0.090 & \multicolumn{2}{|c|}{ Not used for VPI } & \\
\hline $970423 / 82$ & 0.000 & 0.100 & 4 and $30^{\circ} \mathrm{C}$ & $\mathrm{CG}$ and $\mathrm{S}$ & $0 / 164$ \\
\hline Healthy corn & 0.004 & 0.113 & & & \\
\hline $9712-2-1$ & 0.406 & 0.020 & $30^{\circ} \mathrm{C}$ & $\mathrm{S}$ & $23 / 100$ \\
\hline Y-4 & 0.015 & 0.048 & $30^{\circ} \mathrm{C}$ & $\mathrm{S}$ & $0 / 100$ \\
\hline Healthy corn & 0.010 & 0.023 & & & \\
\hline
\end{tabular}

${ }^{a}$ Grown from seed obtained from corn naturally infected by High Plains virus (HPV).

${ }^{\mathrm{b}}$ ELISA values of HPV-infected source plants against HPV and Wheat streak mosaic virus (WSMV) antisera.

${ }^{c}$ Corn cultivars Country Gentleman (CG) or Spirit (S) used in VPI. control value of 0.018 against HPV antiserum). Extracts from a control plant from the grow-out test (symptomless and tested negative in ELISA for both HPV and WSMV) did not cause infection of corn by the vascular puncture inoculation procedure. In the next vascular puncture inoculation transfer, two plants were used, 9712-21 (symptomatic and positive in ELISA for only HPV) and Y-4 (control from grow-out plants; symptomless and negative in ELISA for HPV and WSMV). Extracts from 9712-2-1 caused infection of 23/100 corn assay plants, each symptomatic and testing positive in ELISA for only HPV (values ranged from 0.103 to 0.228 , HPV control $=0.129$, and healthy control $=$ 0.012), and extracts from Y-4 did not cause infection. Thus, two methods (mite transfer and vascular puncture inoculation) confirmed the ELISA results that corn plants from seed grow-out tests were infected by HPV.

\section{DISCUSSION}

Seed transmission of HPV has been demonstrated in a greenhouse at high temperatures, but we have no evidence that this would occur under field conditions. The high temperatures employed in this study aid in symptom expression, but are unlikely to occur during seedling emergence in most corn growing areas.

Furthermore, even if one or a few infected seedlings survived to maturity, little is known about the dynamics of the $A$. tosichella population to predict whether an epidemic could ensue. It is not likely that those few plants could serve as significant inoculum sources for secondary spread within the corn field leading to an epidemic, because mites merely drift on wind currents rather than flying and seeking a host. This is in contrast to a virus such as MDMV, which is seedborne and nonpersistently transmitted by aphids. Massive flights of cereal aphids emigrating from weeds, other host crops, or maturing wheat fields can result in a dramatic increase in the incidence of MDM in a relatively short period of time. Furthermore, the symptoms of HPV-infected corn are most severe when plants are infected while very young, and there would not be time for the mite population to build up and spread to surrounding plants before the plants had passed the most vulnerable seedling stage. Where sweet corn is planted sequentially over several weeks, it is possible that the mite population could build up on the early plantings and transmit HPV to later plantings, causing more problems. However, the greatest threat might be from even a few mites being blown from a diseased seedling and carrying HPV into surrounding perennial hosts, from where it could spread to subsequent crops.

Because HPV is transmitted by A. tosichella, we were conscious of the potential for stray mites in the test area to transmit 
HPV from some other source and confound the results. Consequently, we conducted the grow-out tests in the winter and early spring when mites were unlikely to be present due to freezing temperatures, snow cover, and dead or dormant host plants near the greenhouse. Furthermore, we placed pots of indicator wheat seedlings among the trays of corn seedlings and observed the wheat and corn seedlings frequently for symptoms of mite infestation. No wheat plants with symptoms indicating the presence of mites or wheat streak mosaic virus were observed.

The disease caused by HPV is selfeliminating from two standpoints: lack of seed production and early plant death. During the survey of HPV-infected corn seed fields, it was observed that about 50 to $60 \%$ of infected plants did not produce an ear or produced only a vestigial ear without any seed; the range was from a trace to virtually $100 \%$. The balance of infected plants produced small ears and limited seed. In the grow-out tests, HPVinfected plants did not survive past the sixor seven-leaf stage.

After a positive ELISA, infected seedlings were carefully transplanted with a large root ball to $20-\mathrm{cm}$-diameter pots to eliminate competition from surrounding plants in the seed trays. They produced one or two new symptomatic leaves after transplanting but died within a few weeks. Healthy check plants that were transplanted in a similar manner suffered almost no transplanting shock and flourished. It is a common observation that susceptible seedlings inoculated with HPV may die within a few weeks after infection. Certainly seed transmission would occur even earlier and probably be more damaging.

The source of the WSMV in 13 indicator barley plants in the transfer of mites from plant 35A-1 could possibly have been from the presence of WSMV in the mite colony; however, this seems unlikely because plant 35A-1 had an ELISA value of 0.016 against WSMV antiserum compared with the healthy wheat control value of 0.016, while the WSMV positive control was 0.708 . However, since no WSMV infection of barley was observed from the mites not exposed to the 35A-1 sample and none was detected in the culture, it is possible that a low level of WSMV existed in 35A-1 and was acquired and transmitted along with the HPV. Seed transmission of WSMV in corn has previously been reported (4). To avoid any further ambiguities, the confirmation of HPV in tissue positive in ELISA was done by vascular puncture inoculation to remove any complication from the mites. The two vascular puncture inoculation tests (plants 9706-6-1 and 9712-2-1, see Table 1) resulted in infection of corn through seed inoculation and confirmed the presence of HPV in plants positive in ELISA, as did the mite transfer.

These results also underscore the complexity of defining corn disease(s) associated with $A$. tosichella, especially those caused by WSMV and HPV. Indeed, mixed infections of WSMV and HPV are commonly detected in corn and produce symptoms virtually identical to those of corn infected with only HPV. Additionally, several virus pathogens, including one or more unreported and unidentified ones (D. L. Seifers, unpublished), may also be associated with corn plants exhibiting symptoms typical of those commonly associated with HPV-infected plants. Wheat spot mosaic (17) and wheat spot chlorosis (11) are two diseases that share similar symptoms and vectors and may be associated with or related to the disease caused by HPV.

Most of the seeds in this study were derived from hand-harvested ears from corn fields or plots in which a subset of symptomatic plants tested positive in ELISA for HPV. The intent of hand harvesting ears from symptomatic plants was to increase the probability of detecting any HPVinfected seeds that might have been present instead of assaying commercial seed, which presumably has a much higher percentage of seed derived from HPV-free plants. Three of the seed lots that we tested, however, were commercial lots submitted by a seed company. Seeds from two of the three lots produced a total of four symptomatic, ELISA-positive plants, two of which were confirmed by vascular puncture inoculation as described above (the third positive plant in this study was confirmed by mite transfer as described above). The transmission rates of HPV in those two seedlots were 0.10 and $0.11 \%$. Thus, our results indicate that HPV is seed transmitted at a low level in the corn lines used in this study, a phenomenon consistent with other viruses infecting corn $(4,7,10,16,19,20)$.

\section{LITERATURE CITED}

1. Ahn, K.-K., Kim, K. S., Gergerich, R. C., and Jensen, S. G. 1998. High plains disease of corn and wheat: Ultrastructural and serological aspects. J. Submicrosc. Cytol. Pathol. 30:563-571.

2. Clark, M. F., and Adams, A. N. 1977. Characteristics of the microplate method of enzymelinked immunosorbent assay for the detection of plant viruses. J. Gen. Virol. 34:475-483.

3. Forster, R. L., Strausbaugh, C. A., Jensen, S. G., Ball, E. M., Harvey, T., and Seifers, D. L. 1997. Seed transmission of the High Plains virus in sweet corn. (Abstr.) Phytopathology 87:S31

4. Hill, J. H., Martinson, C. A., and Russell, W. A. 1974. Seed transmission of maize dwarf mosaic and wheat streak mosaic viruses in maize and response of inbred lines. Crop Sci. 14:232-235.

5. Jensen, S. G., and Hall, J. S. 1995. Molecular characterization of a viral pathogen infecting maize and wheat in the high plains. (Abstr.) Phytopathology 85:1211.

6. Jensen, S. G., Lane, L. C., and Seifers, D. L. 1996. A new disease of maize and wheat in the high plains. Plant Dis. 80:1387-1390.

7. Jensen, S. G., Wysong, D. S., Ball, E. M., and Higley, P. M. 1991. Seed transmission of maize chlorotic mottle virus. Plant Dis. 75:497-498.

8. Louie, R. 1995. Vascular puncture of maize kernels for the mechanical transmission of maize white line mosaic virus and other viruses of maize. Phytopathology 85:139-143.

9. Louie, R., and Seifers, D. L. 1996. Transmission of the High Plains pathogen by vascular puncture inoculation. (Abstr.) Phytopathology 86:S1.

10. Mikel, M. A., D’Arcy, C. J., and Ford, R. E. 1984. Seed transmission of maize dwarf mosaic virus in sweet corn. Phytopathol. Z. 110:185-191

11. Nault, L. R., Styer, W. E., Gordon, D. T. Bradfute, O. E., LaFever, H. N., and Williams, L. E. 1970. An eriophyid-borne pathogen from Ohio, and its relation to wheat spot mosaic virus. Plant Dis. Rep. 54:156-160.

12. Scholthof, K.-B. G., and Scholthof, H. B. 1995. Strategies toward molecular characterization of the high plains diseases. Pages 2329 in: Proceedings of the High Plains Disease Symposium. C. M. Rush and G. J. Michels, Jr., eds. Texas A\&M University, Amarillo.

13. Seifers, D. L., Harvey, T. L., Martin, T. J., and Jensen, S. G. 1997. Identification of the wheat curl mite as the vector of the High Plains virus of corn and wheat. Plant Dis. 81:1161-1166.

14. Seifers, D. L., Harvey, T. L., Martin, T. J., and Jensen, S. G. 1998. A partial host range of the high plains virus of corn and wheat. Plant Dis. 82:875-879.

15. Seifers, D. L., Martin, T. J., Harvey, T. L., and Gill, B. S. 1995. Temperature sensitivity and efficacy of wheat streak mosaic virus resistance derived from Agropyron intermedium. Plant Dis. 79:1104-1106.

16. Shepard, R. J., and Holdeman, Q. L. 1965 Seed transmission of the johnsongrass strain of sugar cane mosaic virus in corn. Plant Dis. Rep. 49:468-469.

17. Slykhuis, J. T. 1956. Wheat spot mosaic, caused by a mite-transmitted virus associated with wheat streak mosaic. Phytopathology 46:682-687.

18. Timian, R. G. 1974. The range of symbiosis of barley and barley stripe mosaic virus. Phytopathology 64:342-345.

19. Williams, L. E., Findley, W. R., Dollinger, E. J., and Ritter, R. M. 1968. Seed transmission of maize dwarf mosaic virus in corn. Plant Dis. Rep. 52:863-864.

20. Zhu, F. C., Chen, Y. T., Zhang, H. F., and Tsai, J. H. 1982. Identification, transmission, host range, and epidemiology of maize dwarf mosaic virus in northeastern China. Proc. Int. Maize Virus Dis. Colloq. Workshop. L. R. Nault, ed. 